\title{
Perception and intention in organic agriculture cultivation in North Maluku Province
}

\author{
Ikhsan Fuady $^{1 *}$, Mardianah ${ }^{2}$, MA Syifaa Sutarjo ${ }^{3}$ \\ ${ }^{1}$ Padjadjaran University, Kampus Jatinangor J1 Ir. Soekarno, Jatinangor, West Java, Indonesia \\ ${ }^{2}$ Assessement Institute for Agricultural Technology of Maluku Utara, Jl. Inpres Ubo-ubo 241, South \\ Ternate, North Maluku, Indonesia \\ ${ }^{3}$ Telkom University, Jl. Telekomunikasi No. 01, South Buah Batu, West Java, Indonesia
}

\begin{abstract}
The green revolution program during the New Order era has left various agricultural problems. Organic agriculture as the antithesis of agricultural development paradigm has long been echoed. However, the intention of farmers to do organic farming is still relatively limited. Many factors influence farmers' behavior intention, one of which is the perception of agriculture towards the organic farming system. This study aims to describe farmers' perceptions and intention in organic farming in North Maluku Province, using the UTAUT1 (Venkatest 2003) theoretical framework from venkatest. This study was designed as a quantitative study with a survey approach. The population of this study was vegetable farmers in North Maluku province. The sample of this study was 120 farmers spread across the city of Ternate and Tidore. This research data analysis used descriptive statistics. The results showed that the farmers' perceptions about organic agricultural cultivation were generally categorized as quite good / moderate. Only 1 indicator of a high perspective, namely farmers' perceptions of performance expectations or farmers believe that organic farming systems can improve their farming with a value of $3.38 \pm 0.6$. The intention or intention of farmers to do organic farming is relatively diverse. As many as 36.7 percent have a strong desire, but 33.3 percent have a low intention.
\end{abstract}

\section{Introduction}

In Indonesia the rapidly growing green revolution of the 1980s brought significant changes to Indonesia's agricultural system. The agricultural system driven by modern groups makes agriculture a commercial business activity orientedt owards agricultural productivity. This condition made Indonesia experience food self-sufficiency.

The agricultural system developed during the green revolution was a modern agricultural system that was heavy in input. Chemical fertilizers, synthetic pesticides, and agricultural mechanization are the agricultural system'sdriving forces. Behind the success of this green revolution program, it has a destructive impact in the long term, both for human health and the environment [1]. Decreased productivity, higher soil erosion, water

\footnotetext{
* Corresponding author : ikhsan.fuady@unpad.ac.id
} 
contamination, depletion of natural resources, reduced soil fertility, micro nutrient deficiencies, soil contamination, environmental pollution, pest and disease resistance due to ecosystem disturbances are factors.

This farming system has become a big problem nowadays. Along with the criticism of the green revolution program, this agricultural system'santithesis is the development of various eco-friendly agricultural models as a new sustainable paradigm. One model of a sustainable agricultural system is the organic farming system. This agricultural system prioritizes the use of environmentally friendly local resources.

Although the organic farming system has long been introduced globally, development in developing countries, including Indonesia, is relatively slow. In the world, organic agriculture only contributes 1 percent of the world's agricultural land [2]. Many factors become obstacles and challenges in applying organic farming systems, bothfrom the aspects of government policies and public awareness. From government policy, developing countries prioritize state foodsecurity over foods ecurity and environmental sustainability [3]. Also, organicf arming is mainly carried out by firms or companies than farmers[4]. Meanwhile, many studies show that farmers in developing countries, eventhough there is awareness, are still very much $[2,5]$.

Many factors influence individuals to adopt organic farming systems. Davis [6] revealed that the factors that influence individual behavior to embrace innovation are the perceptions of the individual. Furthermore, he also revealed that perception consists of perceived usefulness (perceived ease of use). Then Venkatesh and Davis [7] developed into UTAUT theory, composed of four dimensions of perception: performance expectancy, Effort Expectancy, Social Influence, and Facilitating Conditions [8]. Analyzing and describing farmers 'perceptions of agricultural systems is expected to provide an overview of the determinants of farmers' intention in doingso. This study will examine and represent how farmers' perceptions and intentions of organic agriculture in North Maluku are based on the above background. In explaining the dimensions of farmers' perceptions of organic agriculture, this study uses the UTAUT 1 theoretical framework, which consists of four dimensions, namely [7] :

1. Perceived performance expectancy refers to individual perceptions of the degree to which individuals believe organic farming systems can improve their farming.

2. Effort Expectancy refers to the perception of the degree of convenience that is carried out by implementing an organic farming system,

3. Social Influence perception refers to the view of individual farmers towards the support of those closest to doing organic farming and

4. Facilitating Conditions, namely farmers' perceptions of the availability of existing facilities to support the organic farming system

\section{Research methods}

This research was conducted using a survey approach. This research was conducted from January 2020 to February 2020. The research was conducted in Ternate and Tidore City.

This study was designed as survey method. Survey method was a research with the characteristics of collecting data fromrespondentsusing a questionnaire[9]. The population of this study was the vegetable farmers in Ternate and Tidore City. The sampling was done by convenience sampling. The sample taken in this study was 120 respondents.

The observation variable was the farmers' perceptions of organic agriculture using the UTAUT theoretical framework. The dimensions of the perception in this study were :

a. Perceived performance expectancy refers to individual perceptions of the degree to which individuals believe organic agriculture system can improve their farms. 
b. Effort Expectancy refers to the perception of the degree of convenience carried out by implementing an organic agriculture system,

c. The perception of Social Influence refers to the individual farmer's view of the support of the closest person to do organic agriculture, and,

d. Facilitating Conditions, namely farmers' perceptions of how much the availability of existing facilities to support the organic agriculture system.

The research data were tabulated in excel, and descriptive statistic alanalysis was performed using mean, standard deviation, and the percentage used SPSS for windows 16.0. The scale of the perceptions and intentions of organic agriculture categories is group edusing three categories, namely:

1. High if : $\mathrm{x}>\ddot{\mathrm{x}}+0.5$. $\mathrm{S}$

2. Moderate if : $\ddot{x}-0.5 . S<x \leq \ddot{x}+0.5 . \sigma$

3. Low if : $\mathrm{x} \leq \ddot{\mathrm{x}}-0.5 \mathrm{~S}$.

$$
s=\sqrt{\frac{1}{N-1} \sum_{i=1}^{N}\left(x_{i}-\bar{x}\right)^{2}}
$$

\section{Results and discussion}

Individual behaviour in taking action is stronglyinfluenced by beliefs or perceptions of the action itself. The echo of organic farming is increasingly widespread, as a form of criticism of conventional agricultural systems that tend to damage the environment. The campaign on the importance of environmentally friendly agriculture has spread to remote areas of Indonesia. However, this organic agriculture system is still far from beingi mplemented by small farmers[2].

Individual perceptions of the innovation itself largely determine the determinant factors that influence the desire to use innovation. This study analyzed the perceptions of the farmers in North Maluku on organic agriculture. Based on the results of the analysis, the farmers' perceptions of organic agriculture are illustrated in Table 1 below.

Table 1. Mean and standard deviation of mineral perceptions of organic agriculture cultivation

\begin{tabular}{|l|c|c|c|}
\hline \multicolumn{1}{|c|}{ Variables } & Mean & SD & Category \\
\hline Facilitating condition & 2,83 & 0,60 & Moderate \\
\hline Performance expectancy & 3,38 & 0,60 & High \\
\hline Effort expectancy & 2,87 & 0,50 & Moderate \\
\hline Social influence & 3,12 & 0,56 & Moderate \\
\hline Intention behaviour & 2,92 & 0,64 & Moderate \\
\hline Mean & $\mathbf{3 , 0 2}$ & $\mathbf{0 , 5 8}$ & \\
\hline
\end{tabular}

Source : research data analysis

Based on Table 1, the farmers' assessment of the organic farming system is in the medium category. Farmers' perceptions about the organic agriculture model can increase the sales results in the high category. The farmers believe that organic agriculture system can improve their farming. The lowest perception of the farmers is the perception of ease (effort expectancy). The farmers think that to do 100 organic farming is a difficultt hing. This is in line with the research results, which show that the difficulty of marketing products, building partnerships, and supporting policies are inadequate [5]. For the desire (intention) of the farmers to do organic farming is in the medium category. This is also in 
line with the research results [5]that public awareness begins to grow, although slowly. This is in line with other research, which show tha torganic agriculture is experiencing growth but is still moderate[10].

\subsection{Farmers' perceptions of the performance expectancy of organic farming systems}

Perceived performance expectancy refers to individual perceptions of the degree to which individuals believe organic agriculture system can improve their farming. Based on the results of the analysis, the farmers' perceptions of the performance of organic agriculture are described in Table 2 below.

Table 2. Frequency distribution of performance expectancy perception on organic agriculture cultivation

\begin{tabular}{|l|c|c|c|}
\hline \multirow{4}{*}{ Performance expectancy } & \multirow{2}{*}{\begin{tabular}{c} 
Degree \\
\cline { 2 - 3 }
\end{tabular}} & Frequency & Percentage \\
\cline { 2 - 4 } & High & $\mathbf{( n )}$ & $\mathbf{( \% )}$ \\
\cline { 2 - 4 } & Moderate & 73 & 60,8 \\
\cline { 2 - 4 } & Low & 34 & 28,4 \\
\cline { 2 - 4 } & Total & 13 & 10,8 \\
\hline
\end{tabular}

Source : research data analysis

Table 2 above shows that farmers' perceptions of the performance or increase in organic agriculture income are primarily high. Only 10.8 percent of the respondents stated that organic agriculture is no better than conventional farming. The farmers considered that if organic agriculture is carried out correctly and according to standards, its selling price is much higher than traditional agricultural products.

\subsection{Farmers' perceptions of facilitating conditions for the organic agriculture system}

Facilitating Conditions refers to farmers' perceptions of how much the availability of existing facilities to support the organic farming system. Based on the results of the analysis, farmers' perceptions of support for organic agriculture facilities are described in table 3 below:

Table 3. Frequency distribution of facility support perception for organic agriculture cultivation

\begin{tabular}{|l|l|l|l|}
\hline \multirow{5}{*}{$\begin{array}{c}\text { Degree } \\
\text { of Avilability }\end{array}$} & \multicolumn{1}{|c|}{ Frequency } & \multicolumn{1}{c|}{ Percentage } \\
\cline { 3 - 4 } & (n) & \multicolumn{1}{c|}{$\mathbf{( \% )}$} \\
\hline \multirow{3}{*}{ Fasilitating condition } & High & 22 & 18,3 \\
\cline { 2 - 4 } & Moderate & 63 & 52,5 \\
\cline { 2 - 4 } & Low & 35 & 29,2 \\
\cline { 2 - 4 } & Total & 120 & 100 \\
\hline
\end{tabular}

Source : research data analysis

Table 3 above shows that, in general, the farmers' perceptions of the availability of supporting facilities are in the moderatec ategory. The farmers who assessed limited facilities are more significantthan the ones who valued supporting facilities. According to the farmers' assessment, the nursery and production periodalso the availability of production facilitiessuch as manure and vegetable pesticides are relatively adequate. However, most of the responses assessed that marketing with competitive prices is complex for the farmers to do. 


\subsection{Farmers' perceptions of the effort expectancy of organic farming systems}

Effort Expectancyrefers to the perception of the degree of convenience carried out by implementing an organic farming system. The distribution of respondents based on the perceived ease of doing organic farming is illustrated in Table 4 below.

Table 4. Frequency distribution of the ease level perception in organic agriculture cultivation

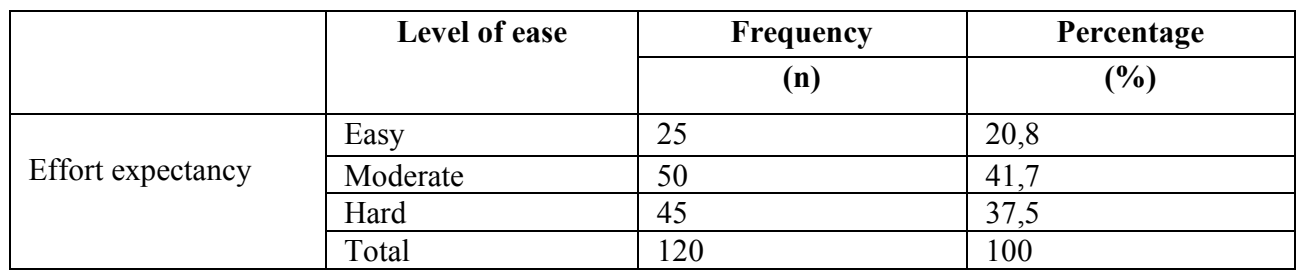

Source : research data analysis

Based on table 4 above, farmers' views or beliefs on the level of ease of doingorganic agriculture are relatively diverse. However, most of the respondentsratedorganic agriculture in the moderate and challengingcategories.

\subsection{Farmers' perceptions of the support of their closest people (social influence) in the cultivation of organic agriculture}

Social Influence refers to the individual farmer's view of the support of the closest related person to him in organic farming.[7] Social influence refers to family support, which are considered essential, such as community leaders and agricultural extension workers.

Based on the results of the analysis, farmers' perceptions of support for organic agriculture facilities are illustrated in Table 5 below.

Table 5. Frequency distribution of the closes relatedperson's support perception in organic agriculture cultivation

\begin{tabular}{|l|l|c|c|}
\hline \multirow{2}{*}{ Support Level } & Frequency & Percentage \\
\cline { 2 - 4 } & & $(\mathrm{n})$ & $\mathbf{( \% )}$ \\
\hline \multirow{3}{*}{ Social influence } & High & 61 & 50,8 \\
\cline { 2 - 4 } & Moderate & 30 & 25,0 \\
\cline { 2 - 4 } & Low & 29 & 24,2 \\
\cline { 2 - 4 } & & 120 & 100 \\
\hline
\end{tabular}

Source : research data analysis

Support from local people is one of the factorsthat can influence farmers to carry out organic farming. The role of the community tokok, family, or relatives. Based on table 5 above, farmers have various attitudes in support of doing organic farming. However, most of the people aroundwho are considered necessary have great support for organic farming. As many as 50.8 percent of respondents consideredt hat the people around them supported doing organic farming.

\subsection{Farmers' intention in the cultivation of organic agriculture}

Intention refers to farmers' desire to apply organic farming in their agricultural business. The intention of farmers in doing organic agriculture is very influenced by many things. Both from within the farmers such as perceptions, abilities, but also external factors such as government policies, marke tavailability and so on. Based on the results of the analysis of 
farmers' intention in North Maluku to carry out organic agriculture, it can be described in Table 6 below.

Table 6. Farmers' intention to do organic agriculture

\begin{tabular}{|l|l|c|c|}
\hline \multirow{2}{*}{ The level of desire } & Frequensy & Percentage \\
\cline { 3 - 4 } & & $(\mathrm{n})$ & $(\%)$ \\
\hline \multirow{3}{*}{ Intention } & High & 44 & 36,7 \\
\cline { 2 - 4 } & Moderate & 36 & 30,0 \\
\cline { 2 - 4 } & Low & 40 & 33,3 \\
\cline { 2 - 4 } & Total & 120 & 100 \\
\hline
\end{tabular}

From the results of the analysis above, it is known thatf armers' intention in doing organic agriculture is relatively diverse. As many as 36 percent of farmers have a high intntion in organic farming, 33.3 percent of them have a low intention in doing organic agriculture. This shows that there are still several farmers maintaining conventional farming models that are heavy in input both in chemical fertilizers and pesticides. This is in line with the research, which show that organic agriculture is experiencing growth but is still very slow $[2,5]$.

\section{Conclusion}

The perceptions of farmers about organic agriculture are generally categorized as quite good/moderate. Only one indicator of a high perspective, namely farmers' perceptions of performance expectations or farmers believe that organic agriculture system can improve their farming with a value of $3.38 \pm 0.6$.

The intention of the farmers to do organic agriculture is relatively diverse. As many as 36.7 percent have a strong intention while 33.3 percent have a low intention.

\section{Reference}

1. R. W. E. L. Ikhsan Fuady, Djuara P. Lubis, J. Komun. Pembang 10 (2), 10-18, (2012)

2. E. M. Meemken and M. Qaim, Annu. Rev. Resour. Econ. 10, 39-63, (2018).

3. S. Schoonbeek, H. Azadi, H. Mahmoudi, B. Derudder, P. De Maeyer, and F. Witlox, Crit. Rev. Food Sci. Nutr. 53(9), 917-928 (2013)

4. H. Tanrivermiş, Pakistan Journal of Biological Sciences. 9(6), 1192-1204, (2006)

5. H. Mayrowani, Forum Penelit. Agro Ekon 30(2) (2016)

6. F. D. Davis, MIS Q. Manag. Inf. Syst. 13(3), 319-339 (1989)

7. V. Venkatesh and F. D. Davis, Manage. Sci. 46(2), 186-204, (2000)

8. A. Chang, The Winners 13(2) (2012)

9. S. E. Masri Singarimbun, Metode penelitian survai. (LP3S, Jakarta, 1989).

10. I. Fuady, J. Komun. Pembang. 10(2) 10-18, (2012) 